\title{
PRZEPISY REGULUJĄCE ZARZĄDZANIE DOKUMENTACJĄ NA PRZEDPOLU ARCHIWALNYM BLIŻSZYM W SĄDACH POWSZECHNYCH W POLSCE W LATACH 1985-2019. WYBRANE PROBLEMY
}

Słowa kluczowe: zarządzanie dokumentacją, archiwum zakładowe, instrukcja archiwalna, przedpole archiwalne, sądy powszechne

\section{Streszczenie}

W grudniu 2018 r. opublikowano zarządzenie Ministra Sprawiedliwości wprowadzające instrukcję w sprawie organizacji i zakresu działania archiwów zakładowych m.in. w sądach powszechnych. Fakt ten przyjęto zapewne $\mathrm{z}$ wielkim entuzjazmem, bowiem poprzednia instrukcja archiwalna obowiązywała od 1985 r. Zmieniający się ustrój państwa, znacznie wyższy poziom świadomości społeczeństwa w kwestii roli prawidłowego zarządzania dokumentacją, w tym także sądową, oraz rozwój nowoczesnych technologii sprawiły, że instrukcja, obowiązująca przez ponad 30 lat, nie przystawała już do rzeczywistości i dostarczała sporych problemów archiwistom zatrudnionym w sądowych archiwach zakładowych. Celem artykułu jest przegląd aktów prawno-normatywnych w zakresie zarządzania dokumentacją obowiązujących w archiwach zakładowych sądów powszechnych w latach 1985-2019. Ze względu na różnorodność załatwianych przez sądy spraw oraz masowość wytwarzanej przez te jednostki dokumentacji, liczbę aktów prawnych regulujących wyżej wspomniane zagadnienia należy uznać za imponującą. Szczegółowej analizie poddano kluczowe dla zarządzania fragmenty aktualnej instrukcji archiwalnej oraz rozporządzenia Ministra Sprawiedliwości z dnia 5 marca $2004 \mathrm{r}$. w sprawie przechowywania akt spraw sądowych i ich przekazywania do archiwów państwowych lub do zniszczenia. 
DOROTA DRZEWIECKA

ORCID 0000-0001-7341-0754

dorota.drzewiecka@up.krakow.pl

(Pedagogical University of Krakow)

\title{
PROVISIONS REGULATING DOCUMENTATION MANAGEMENT IN THE ARCHIVES OF COURTS OF GENERAL JURISDICTION IN POLAND IN THE YEARS 1985-2019
}

Keywords: documentation management, institutional archives, archive instruction, archival foreground, courts of general jurisdiction

\begin{abstract}
In December 2018, Minister of Justice issued an order with instructions on the organization and scope of activities of institutional archives, e.g. in courts of general jurisdiction. It must have been welcomed with enthusiasm because the previous archive instruction came into force in 1985 . The changing political system in Poland, a significantly higher level of social awareness on the significance of documentation management, also in courts, and the development of modern technologies made the 30-year old instruction outdated, which started causing considerable problems to archivists employed in court archives. The aim of this article is to review legal and normative acts implemented in the years 1985-2019 which concerned documentation management in institutional archives in courts of general jurisdiction. Due to the variety of cases considered by courts and the fact that these institutions compile documentation in massive numbers, the number of applicable legal acts is also impressive. The author analyses in detail key excerpts from the current archive instruction and Minister of Justice Regulation of 5 March 2004 on storing case files and transferring them to state archives or to be destroyed.
\end{abstract}


Zasadnicze znaczenie istnienia poprawnych, rzetelnych, kompletnych, a także spójnych aktów prawa jest bezsprzeczne w każdej dziedzinie życia. Funkcjonowanie prawa było i - zapewne jeszcze nie raz - będzie tematem wielu konferencji, sympozjów, artykułów, a nawet odrębnych monografii. Kwestia ta jest równie ważna dla przedpola archiwalnego (dalszego i bliższego). Niniejsze rozważania poświęcono aktom prawno-normatywnym regulującym zarządzanie dokumentacją na przedpolu archiwalnym bliższym, czyli w archiwach zakładowych w sądach powszechnych - grupie podmiotów szczycących się mianem jednego z największych twórców narodowego zasobu archiwalnego. Celem artykułu jest przegląd aktów prawno-normatywnych obowiązujących w latach 1985-2019. Przy wykorzystaniu metody historyczno-ustrojowej szczegółowej analizie poddano kluczowe dla zarządzania fragmenty aktualnej instrukcji archiwalnej oraz rozporządzenia Ministra Sprawiedliwości z dnia 5 marca 2004 r. w sprawie przechowywania akt spraw sądowych oraz ich przekazywania do archiwów państwowych lub do zniszczenia.

W grudniu 2018 r. opublikowano zarządzenie Ministra Sprawiedliwości $^{1}$ w sprawie instrukcji w sprawie organizacji i zakresu działania archiwów zakładowych w jednostkach organizacyjnych podległych Ministrowi Sprawiedliwości lub przez niego nadzorowanych, które weszło w życie 1 stycznia 2019 r. $^{2} \mathrm{~W}$ archiwach zakładowych resortu sprawiedliwości fakt ten przyjęto zapewne $\mathrm{z}$ wielkim entuzjazmem, bowiem poprzednia instrukcja archiwalna obowiązywała od 1985 r. $^{3}$ Zmieniający się ustrój państwa, nowe przepisy kancelaryjno-archiwalne w innych instytucjach, znacznie wyższy poziom świadomości społeczeństwa w zakresie roli prawidłowego zarządzania dokumentacją, w tym także sądową, oraz rozwój nowoczesnych technologii sprawiły, że instrukcja, obowiązująca przez ponad 30 lat, nie przystawała już do rzeczywistości i dostarczała sporych problemów archiwistom zatrudnionym $\mathrm{w}$ archiwach bieżących resortu sprawiedliwości.

${ }^{1}$ Zgodnie z art. $53 \S 4$ ustawy z dnia 27 lipca 2001 r. Prawo o ustroju sądów powszechnych (Dz.U. 2020, poz. 365), Minister Sprawiedliwości określa okres niezbędny do przechowywania akt w sądzie, a także warunki i tryb przechowywania akt oraz warunki i tryb ich niszczenia.

${ }^{2}$ Zarządzenie Ministra Sprawiedliwości z dnia 14 grudnia 2018 r. w sprawie instrukcji w sprawie organizacji i zakresu działania archiwów zakładowych w jednostkach organizacyjnych podległych Ministrowi Sprawiedliwości lub przez niego nadzorowanych. Załącznik do zarządzenia: Instrukcja w sprawie organizacji i zakresu działania archiwów zakładowych w jednostkach organizacyjnych podległych Ministrowi Sprawiedliwości lub przez niego nadzorowanych [dalej: Instrukcja archiwalna z 2018 r.] (Dz. Urz. Ministra Sprawiedliwości 2018, poz. 348). Aktualny wykaz jednostek podległych Ministrowi Sprawiedliwości lub przez niego nadzorowanych znajduje się w obwieszczeniu Ministra Sprawiedliwości z dnia 7 lutego 2020 r. w sprawie wykazu jednostek podległych Ministrowi Sprawiedliwości lub przez niego nadzorowanych (M.P. 2020, poz. 241).

${ }^{3}$ Zarządzenie Ministra Sprawiedliwości z dnia 30 grudnia 1985 r. w sprawie archiwów zakładowych $\mathrm{w}$ jednostkach organizacyjnych resortu sprawiedliwości. Załącznik do zarządzenia: Instrukcja w sprawie organizacji i zakresu działania archiwów zakładowych w resorcie sprawiedliwości [dalej: Instrukcja archiwalna z 1985 r.] (Dz. Urz. Ministra Sprawiedliwości 1985, nr 8, poz. 55). 
Treść zarządzenia przyjęta została w porozumieniu z Naczelnym Dyrektorem Archiwów Państwowych.

Obowiązek posiadania instrukcji w sprawie organizacji i zakresu działania archiwów zakładowych wynika z zapisu art. 6 ustawy o narodowym zasobie archiwalnym i archiwach ${ }^{4}$. Tak zwana instrukcja archiwalna jest zbiorem zasad, metod, norm i szczegółowych wskazówek wyjaśniających i opisujących czynności wykonywane w archiwach bieżących. W wypadku jednostek wymiaru sprawiedliwości nie można analizować kwestii dotyczących zarządzania dokumentacją $\mathrm{w}$ archiwum zakładowym na podstawie jednego tylko aktu prawnego. Należy uwzględnić także inne rozporządzenia lub zarządzenia Ministra Sprawiedliwości regulujące postępowanie $\mathrm{z}$ dokumentacją $\mathrm{w}$ sądowych archiwach zakładowych. Wśród najważniejszych przepisów szczegółowych trzeba wymienić dwa rozporządzenia Ministra Sprawiedliwości w sprawie okresów przechowywania i warunków niszczenia akt spraw sądowych lub przekazywania ich archiwom państwowym, wydane kolejno: 6 grudnia 1975 r. i 5 maja 1989 r. ${ }^{5}$, następnie rozporządzenie z 5 marca $2004 \mathrm{r}$. w sprawie przechowywania akt spraw sądowych oraz ich przekazywania do archiwów państwowych lub do zniszczenia ${ }^{6}$, rozporządzenie z 14 lutego 2000 r. w sprawie ustalenia warunków i okresów czasu, po których akta spraw o wykroczenia podlegają zniszczeniu w całości lub w części albo przekazaniu archiwom państwowym ${ }^{7}$, rozporządzenie z 21 grudnia $2000 \mathrm{r}$. w sprawie sposobu przekazywania dotychczasowych rejestrów i przekazywania

${ }^{4}$ Ustawa z dnia 14 lipca 1983 r. o narodowym zasobie archiwalnym i archiwach (t.j.: Dz.U. 2020, poz. 164).

${ }^{5}$ Rozporządzenie Ministra Sprawiedliwości z dnia 6 grudnia 1975 r. w sprawie okresów przechowywania i warunków niszczenia akt spraw sądowych lub przekazywania ich archiwom państwowym (Dz.U. 1975, nr 43, poz. 220), rozporządzenie Ministra Sprawiedliwości z dnia 5 maja 1989 r. w sprawie okresów przechowywania i warunków niszczenia akt spraw sądowych lub przekazywania ich archiwom państwowym (Dz.U. 1989, nr 28, poz. 150), zmienione rozporządzeniem Ministra Sprawiedliwości z dnia 11 czerwca 1999 r. zmieniającym rozporządzenie w sprawie okresów przechowywania i warunków niszczenia akt spraw sądowych lub przekazywania ich archiwom państwowym (Dz.U. 1999, nr 57, poz. 602).

${ }^{6}$ Rozporządzenie Ministra Sprawiedliwości z dnia 5 marca 2004 r. w sprawie przechowywania akt spraw sądowych oraz ich przekazywania do archiwów państwowych lub do zniszczenia (Dz.U. 2004, nr 46, poz. 443, t.j.: Dz.U. 2014, poz. 991). Akty zmieniające: rozporządzenie Ministra Sprawiedliwości z dnia 2 grudnia $2011 \mathrm{r}$. zmieniające rozporządzenie w sprawie archiwizowania akt spraw sądowych (Dz.U. 2011, nr 274, poz. 1623); rozporządzenie Ministra Sprawiedliwości z dnia 5 kwietnia 2013 r. zmieniające rozporządzenie w sprawie przechowywania akt spraw sądowych oraz ich przekazywania do archiwów państwowych lub do zniszczenia (Dz.U. 2013, poz. 469); rozporządzenie Ministra Sprawiedliwości z dnia 29 listopada 2019 r. zmieniające rozporządzenie w sprawie przechowywania akt spraw sądowych oraz ich przekazywania do archiwów państwowych lub do zniszczenia (Dz.U. 2019, poz. 2396).

7 Rozporządzenie Ministra Sprawiedliwości z dnia 14 lutego 2000 r. w sprawie ustalenia warunków i okresów czasu, po których akta spraw o wykroczenia podlegają zniszczeniu w całości lub w części albo przekazaniu archiwom państwowym (Dz.U. 2000, nr 12, poz. 148). 
akt rejestrowych oraz wydawania z nich wypisów, wyciągów i zaświadczeń, zarządzenie z 25 lipca 1995 r. w sprawie kwalifikacji do materiałów archiwalnych lub dokumentacji niearchiwalnej akt i ksiąg kolegiów do spraw wykroczeń z lat 1981-1989, okresów ich przechowywania oraz warunków niszczenia lub przekazywania archiwom państwowym ${ }^{9}$, rozporządzenie z 19 listopada $1936 \mathrm{r}$. o niszczeniu odpisów protestów weksli i czeków ${ }^{10}$. Odrębnym regulacjom podlega zarządzanie dokumentacją zawierającą informacje niejawne ${ }^{11}$. Inne przepisy dotyczą także akt wytworzonych w wyniku działalności komorników ${ }^{12} i$ notariuszy ${ }^{13}$ oraz ksiąg wieczystych ${ }^{14}$.

Funkcjonowanie archiwum zakładowego jest ściśle powiązane z kancelarią (rozumianą jako wszystkie komórki organizacyjne wykonujące czynności kancelaryjne oraz wytwarzające dokumentację) każdej jednostki organizacyjnej. Warto zatem wymienić normatywy regulujące także i ten obszar zarządzania dokumentacją. W omawianym temacie będzie to zarządzenie Ministra Sprawiedliwości z dnia 27 kwietnia 1983 r. w sprawie biurowości sądów wojewódzkich i rejonowych (instrukcja sądowa) ${ }^{15}$, a także trzy zarządzenia w sprawie organizacji i zakresu działania sekretariatów sądowych oraz innych działów admini-

${ }^{8}$ Rozporządzenie Ministra Sprawiedliwości z dnia 21 grudnia 2000 r. w sprawie sposobu przekazywania dotychczasowych rejestrów i przekazywania akt rejestrowych oraz wydawania z nich wypisów, wyciągów i zaświadczeń (Dz.U. 2000, nr 117, poz. 1239).

${ }^{9}$ Zarządzenie Ministra Sprawiedliwości z dnia 25 lipca 1995 r. w sprawie kwalifikacji do materiałów archiwalnych lub dokumentacji niearchiwalnej akt i ksiąg kolegiów do spraw wykroczeń z lat 1981-1989, okresów ich przechowywania oraz warunków niszczenia lub przekazywania archiwom państwowym, (Dz. Urz. Ministra Sprawiedliwości, nr 3, poz. 19).

${ }^{10}$ Rozporządzenie Ministra Sprawiedliwości z dnia 19 listopada 1936 r. o niszczeniu odpisów protestów weksli i czeków (Dz.U. 1936, nr 90 poz. 625).

${ }^{11}$ Rozporządzenie Ministra Sprawiedliwości z dnia 20 lutego 2012 r. w sprawie sposobu postępowania z protokołami przesłuchań i innymi dokumentami lub przedmiotami, na które rozciąga się obowiązek zachowania w tajemnicy informacji niejawnych albo zachowania tajemnicy związanej z wykonywaniem zawodu lub funkcji (Dz.U. 2012, poz. 219); rozporządzenie Ministra Sprawiedliwości z dnia 18 czerwca 2003 r. w sprawie postępowania o zachowanie w tajemnicy okoliczności umożliwiających ujawnienie tożsamości świadka oraz sposobu postępowania z protokołami z zeznań tego świadka (t.j.: Dz.U. 2019, poz. 110).

${ }_{12}$ Rozporządzenie Ministra Sprawiedliwości z dnia 7 października 2011 r. w sprawie przechowywania akt spraw komorniczych oraz zamkniętych urządzeń ewidencyjnych (Dz.U. 2016, poz. 370).

${ }^{13}$ Rozporządzenie Ministra Sprawiedliwości z dnia 14 lipca 1986 r. w sprawie prowadzenia ksiąg wieczystych założonych przed dniem 1 stycznia 1947 r. oraz utraty mocy prawnej niektórych takich ksiąg (Dz.U. 1986, nr 28, poz. 141); rozporządzenie Ministra Sprawiedliwości z dnia 12 kwietnia 1991 r. w sprawie prowadzenia ksiąg notarialnych oraz przekazywania na przechowanie dokumentów sądom rejonowym (t.j.: Dz.U. 2018, poz. 2039).

${ }^{14}$ M.in.: rozporządzenie Ministra Sprawiedliwości z dnia 17 września 2001 r. w sprawie prowadzenie ksiąg wieczystych i zbiorów dokumentów (Dz.U. 2001, nr 102, poz. 1122); rozporządzenie Ministra Sprawiedliwości z dnia 21 listopada 2013 r. w sprawie prowadzenia zbioru dokumentów dla nieruchomości, które nie mają założonych ksiąg wieczystych albo których księgi wieczyste zaginęły lub uległy zniszczeniu, oraz postępowania w tych sprawach (Dz.U. 2013, poz. 1397).

${ }^{15}$ Dz. Urz. Ministra Sprawiedliwości 1983, nr 4, poz. 20 z późn. zm. 
stracji sądowej wydane kolejno: 22 lutego 1988 r. ${ }^{16}, 12$ grudnia 2003 r. ${ }^{17}$ oraz aktualnie obowiązujące z 19 czerwca 2019 r. ${ }^{18}$ Wyraźnie trzeba podkreślić, że sprawy dotyczące zarządzania dokumentacją na przedpolu archiwalnym dalszym uregulowane zostały w dwóch typach normatywów. Pierwszym z nich są przedstawione już zarządzenia w sprawie organizacji i zakresu działania sekretariatów sądowych oraz innych działów administracji sądowej, gdzie unormowano kwestie zarządzania dokumentacją z podziałem na rodzaje spraw sądowych, w tym także spraw z zakresu administracji sądowej i nadzoru. Drugim typem są wprowadzone na podstawie wspomnianych aktów prawnych instrukcje kancelaryjne, których zadaniem jest dostosowanie rozwiązań dotyczących postępowania z dokumentacją administracji i nadzoru (wewnętrznego obiegu dokumentacji oraz podziału czynności kancelaryjnych) do ,potrzeb wynikających ze struktury organizacyjnej i warunków działania sądu, z zachowaniem zasady, iż obieg pism i akt pomiędzy poszczególnymi stanowiskami pracy jest ograniczony do niezbędnych punktów zatrzymania" ${ }^{19}$. Wprowadzenie instrukcji kancelaryjnej należy do kompetencji prezesa sądu, który czyni to w porozumieniu z Naczelnym Dyrektorem Archiwów Państwowych ${ }^{20}$. Przyjęty normatyw powinien zawierać przepisy wyjaśniające zasady korzystania z rzeczowego wykazu akt, stanowiąc tym samym jego uzupełnienie ${ }^{21}$. Każdy sąd ma możliwość dostosowania instrukcji kancelaryjnej do własnych potrzeb. Wśród aktów prawnych dotyczących przedpola archiwalnego dalszego znajdują się także dwa ważne rozporządzenia regulujące zagadnienia utrwalania obrazu i dźwięku z przebiegu posiedzenia jawnego $\mathrm{w}$ postępowaniu cywilnym ${ }^{22}$ i dla celów procesowych w postępowaniu karnym ${ }^{23}$.

16 Dz. Urz. Ministra Sprawiedliwości 1988, nr 2, poz. 6 z późn. zm.

17 Dz. Urz. Ministra Sprawiedliwości 2003, nr 5, poz. 22 z późn. zm.

18 Zarządzenie Ministra Sprawiedliwości z dnia 19 czerwca 2019 r. w sprawie organizacji i zakresu działania sekretariatów sądowych oraz innych działów administracji sądowej (Dz. Urz. Ministra Sprawiedliwości 2019, poz. 138).

19 Ibidem, § 567. Podobny zapis występuje także we wcześniejszych wersjach zarządzenia.

${ }^{20}$ Naczelny Dyrektor Archiwów Państwowych upoważnia dyrektorów archiwów państwowych do występowania w jego imieniu; zob.: ustawa z dnia 14 lipca 1983 r. ..., art. 6 ust. 2 i 2 h.

${ }_{21}$ Zarządzenie Ministra Sprawiedliwości z dnia 19 czerwca 2019 r...., § 566.

22 Rozporządzenie Ministra Sprawiedliwości z dnia 10 sierpnia 2011 r. w sprawie zapisu dźwięku albo obrazu i dźwięku z przebiegu posiedzenia jawnego (Dz.U. 2011, nr 175, poz. 1046), zastąpione rozporządzeniem Ministra Sprawiedliwości z dnia 20 marca 2015 r. w sprawie zapisu dźwięku albo obrazu i dźwięku z przebiegu posiedzenia jawnego w postępowaniu cywilnym (Dz.U. 2015, poz. 359) oraz rozporządzeniem Ministra Sprawiedliwości z dnia 10 października 2016 r. zmieniającym rozporządzenie w sprawie zapisu dźwięku albo obrazu i dźwięku z przebiegu posiedzenia jawnego w postępowaniu cywilnym (Dz.U. 2016, poz. 1697).

${ }^{23}$ Rozporządzenie Ministra Sprawiedliwości z dnia 23 grudnia 2015 r. w sprawie utrwalania dźwięku albo obrazu i dźwięku dla celów procesowych w postępowaniu karnym (Dz.U. 2015, poz. 2344), zastąpione rozporządzeniem Ministra Sprawiedliwości z dnia 11 stycznia 2017 r. w sprawie utrwalania obrazu lub dźwięku dla celów procesowych w postępowaniu karnym (Dz.U. 2017, poz. 93). 
Problemy, wynikające z braku odpowiednich normatywów, były niejednokrotnie tematem wystąpień referentów podczas konferencji naukowych lub szkoleniowych. W 2001 r. Stowarzyszenie Archiwistów Polskich zorganizowało Krajowe Sympozjum Archiwalne. Omawiane wówczas problemy zostały zebrane w postaci artykułów, które ukazały się drukiem ${ }^{24}$. Działania zmierzające do stworzenia i wprowadzenia w życie nowej instrukcji archiwalnej były przez wiele lat podejmowane przez archiwistów należących do powstałego pod koniec 2005 r. Stowarzyszenia Archiwistów Instytucji Wymiaru Sprawiedliwości [dalej: SAWS]. Do udziału w corocznych konferencjach organizowanych przez SAWS niejednokrotnie zapraszano reprezentantów Ministerstwa Sprawiedliwo$\mathrm{s}^{\mathrm{c}} \mathrm{i}^{25}$. Sporo kwestii omawiano $\mathrm{w}$ trakcie tzw. paneli dyskusyjnych organizowanych podczas konferencji ${ }^{26}$. Przedstawiciele SAWS wchodzili też w dyskusję z pracownikami Naczelnej Dyrekcji Archiwów Państwowych [dalej: NDAP] ${ }^{27}$.

${ }^{24}$ Archiwa instytucji wymiaru sprawiedliwości w stużbie państwa i obywateli. Materiaty III Krajowego Sympozjum Archiwalnego Łódź, 4-5 września 2001 r., red. J. Baranowski i U. Zarzycka-Sutter, Łódź 2001.

${ }^{25} \mathrm{Na}$ temat projektu nowej instrukcji archiwalnej głos zabierała Kamila Sontowska m.in. w 2015 r. w Szczecinie, w 2016 r. w Warszawie, zob. A. Widawska, Sprawozdanie $z$ XII Konferencji SAWS, Szczecin 6-9 maja 2015 r., http://www.saws.pl/asp/pl start. asp?typ $=13 \&$ sub $=0 \& m e n u=2 \&$ artykul=79\&akcja=artykul [dostęp: 1.12.2020] oraz Sprawozdanie $z$ XIII Konferencji, Warszawa 19-22 kwietnia 2016 r., http://www.saws.pl/asp/pl start. asp?typ $=13 \&$ sub $=0 \&$ menu $=2 \&$ artykul=82\&akcja=artykul [dostęp: 1.12 .2020 ].

${ }^{26}$ Warto w tym miejscu odwołać się do publikacji pokonferencyjnych, w których ukazały się artykuły poświęcone m.in. problemom zarządzania dokumentacją w sądach powszechnych. Zob. min.: S. Kotecka, A. Zalesińska, Problemy prawne i techniczne archiwizowania materiałów z przestuchania na odległość, [w:] Materiały pokonferencyjne Świnoujście 14-17 maja 2009 r. Szczecin 14-17 września 2010 r., praca zbior., Wrocław 2010, s. 29-52; S. Kotecka, Dokument elektroniczny w wymiarze sprawiedliwości - stan obecny, [w:] Materialy pokonferencyjne, Wrocław 2012-2013, praca zbior., Wrocław 2013, s. 2-17; A. Zalesińska, Protokót sądowy sporzadzany za pomoca urzadzeń rejestrujących dźwięk albo obraz i dźwięk, jako dokument elektroniczny i jego archiwizacja, [w:] ibidem, s. 35-37; S. Kotecka. Repertoria, rejestry, protokoły i zataczniki elektroniczne do akt - problemy z archiwizacja, [w:] ibidem, s. 145-152. Na stronie internetowej SAWS znajdują się materiały z XIV, XV i XVI konferencji SAWS: m.in.: E. Perłakowska, Narzędzia informatyczne w bieżacym i archiwalnym zarządzaniu dokumentacja $w$ podmiotach działajacych $w$ systemie tradycyjnym; B. Owczarek, D. Maślak, Centralne Archiwum Protokotów Elektronicznych - status prawny i organizacyjny, (http://www.saws.pl/asp/pl_start.asp?ty$\mathrm{p}=14 \&$ menu=57\&strona=1 [dostęp: 2.12.2020]); E. Perłakowska, Jednolity Rzeczowy Wykaz Akt w jednostkach wymiaru sprawiedliwości, http://www.saws.pl/asp/pl_start.asp?typ=14\&menu=58\&strona=1 [dostęp: 2.12.2020]; I. Fischer, Przekazywanie materiałów archiwalnych do archiwów państwowych w świetle aktualnych przepisów, ibidem; M. Konstankiewicz, Regulacje dotyczące udostępniania dokumentacji przez archiwa instytucji wymiaru sprawiedliwości, ibidem.

27 Zob. m.in. sprawozdanie ze spotkania w NDAP w kwietniu 2014 r.: Stowarzyszenie Archiwistów Instytucji Wymiaru Sprawiedliwości. Z życia SAWS. Spotkanie w NDAP w Warszawie. http://www.saws.pl/asp/pl start.asp?typ $=13 \&$ sub=0\&menu=2\&artykul=73\&akcja=artykul [dostęp: 1.03.2019] i sprawozdanie ze spotkania z Naczelnym Dyrektorem Archiwów Państwowych i jego zastępcą we wrześniu 2012 r.: Stowarzyszenie Archiwistów Instytucji Wymiaru Sprawiedliwości. Z życia SAWS. Spotkanie z Dyrektorami Naczelnymi Archiwów Państwowych, http://www.saws.pl/ asp $/ \mathrm{pl}$ start.asp?typ=13\&sub=0\&menu=2\&artykul=64\&akcja=artykul [dostęp: 1.03 .2019$]$. 
Geneza powstania nowej instrukcji archiwalnej dla sądów powszechnych jest zatem długa. W registraturze SAWS znajdują się materiały poświęcone dyskusjom toczącym się zarówno na kanwie wspomnianych już konferencji, jak i w trakcie spotkań w NDAP. Opracowane wówczas projekty normatywów w znacznym stopniu odbiegają od wprowadzonej w życie instrukcji. Archiwistom zrzeszonym w SAWS zależało na tym, by nowa instrukcja archiwalna uregulowała takie kwestie jak status archiwisty zakładowego, jego wykształcenie, kwalifikacje oraz problem liczebności archiwistów zatrudnionych w jednej komórce organizacyjnej. W tym ostatnim wypadku podstawowym kryterium miał być rozmiar zasobu w archiwum zakładowym. Proponowano zatrudnienie jednego pracownika na każde $700 \mathrm{mb}$. akt. W roboczej wersji instrukcji archiwalnej przygotowanej przez SAWS wyeksponowano rolę ośrodków zarządzania informacją, utworzonych przy sądach powszechnych w celu ,gromadzenia, archiwizowania i udostępniania informacji z nagrań procesów cywilnych, które przechodzą taką zmianę, że nie będą już protokołowane w formie tradycyjnej, tylko będą nagrywane" 28 . W instrukcji z grudnia 2018 r. zagadnienia te w ogóle nie zostały uwzględnione.

Już pierwszy paragraf zarządzenia z 2018 r. sugeruje, że jest to akt uwzględniający, coraz częściej występujące w różnego typu podmiotach, elektroniczne zarządzanie dokumentacją. Świadczą o tym dwa terminy: „skład chronologiczny” i „skład informatycznych nośników danych”. Normodawca zdecydował się zatem na przyjęcie rozwiązania organizacyjnego zaproponowanego w rozporządzeniu Prezesa Rady Ministrów z 18 stycznia 2011 r. ${ }^{29}$, definiując je niemal identycznie. Zaskakujące jest używanie określenia „Elektroniczne Zarządzanie Dokumentacją" pisane wielkimi literami. Wydaje się, że także i ten zapis jest nieprzemyślaną kopią fragmentów rozporządzenia z $2011 \mathrm{r}$., powieloną przez NDAP w projektach normatywów kancelaryjno-archiwalnych zamieszczonych na oficjalnej stronie internetowej w celu usprawniania procesu ich opracowywania przez podmioty publiczne ${ }^{30}$. W ustawie o narodowym zasobie archiwalnym i archiwach mowa jest jedynie o systemie elektronicznego zarządzania dokumentacją ${ }^{31}$. Skąd zatem zapis traktujący elektroniczne zarządzanie dokumentacją jak nazwę własną? Być może rozwiązanie tego problemu znajduje się na

28 Podlasie24 Regionalny Portal Informacyjny. W Siedlcach powstaje Ośrodek Zarządzania Informacją, http://podlasie24.pl/wiadomosci/siedlce/w-siedlcach-powstaje-osrodek-zarzadzaniainformacja-896e.html [dostęp: 13.06.2020]. Zob. także: D. Maślak, Ośrodki Zarzadzania Informacją. Nowa forma archiwizacji, [w:] Materiaty pokonferencyjne, Wroctaw 2012-2013 ..., s. 118-124.

${ }^{29}$ Rozporządzenie Prezesa Rady Ministrów z dnia 18 stycznia 2011 r. w sprawie instrukcji kancelaryjnej, jednolitych rzeczowych wykazów akt oraz instrukcji w sprawie organizacji i zakresu działania archiwów zakładowych (Dz.U. 2011, nr 14, poz. 67).

${ }^{30}$ Archiwa Państwowe. Zarządzanie dokumentacją. Instrukcje i wykazy akt, https://www. archiwa.gov.pl/pl/zarzadzanie-dokumentacja/zarz $\%$ C4\%85dzanie-dokumentacj\%C $4 \% 85 /$ instrukcjei-wykazy-akt/przyk\%C5\%82adowe-instrukcje-kancelaryjne-i-archiwalne [dostęp: 1.06.2020].

${ }^{31}$ Ustawa z dnia 14 lipca 1983 r..., art. 6.1a. 
stronie www.ezd.gov.pl, gdzie zamieszczono informacje dotyczące jednostek organizacyjnych, które wdrożyły lub przygotowują się do wdrożenia systemu EZD autorstwa Podlaskiego Urzędu Wojewódzkiego. Poza Ministerstwem Sprawiedliwości, w którym od października 2016 r. trwają prace wdrożeniowe, na liście znaleźć można także kilka sądów o podobnym statusie w zakresie wprowadzania systemu EZD ${ }^{32}$. Wychodząc naprzeciw tendencji wzrostowej wdrażania tego konkretnego systemu teleinformatycznego, który docelowo zostanie przekształcony w system EZD RP, autorzy instrukcji postanowili uwzględnić właśnie takie rozwiązanie. Nie jest ono kompatybilne z obowiązującym zarządzeniem dotyczącym sekretariatów sądowych. Na próżno bowiem szukać w nim informacji o systemie elektronicznego zarządzania dokumentacją, choć często pojawiają się zapisy o dokumentach elektronicznych. Na tworzenie i przetwarzanie akt z wykorzystaniem technik informacyjnych zezwala za to akt nadrzędny dla sądów - Prawo o ustroju sądów powszechnych ${ }^{33}$. Ciekawe jest brzmienie par. 559.5 sugerujące, że archiwum zakładowe sądu może prowadzić „elektroniczny system ewidencji” ${ }^{\prime 34}$. Instrukcje kancelaryjne sądów też coraz częściej dostosowane są do nowoczesnych wymogów i rozwiązań. Znaleźć możemy takie, w których unormowany jest zakres stosowania systemu EZD lub dedykowanego systemu teleinformatycznego ${ }^{35}$.

Załączona do zarządzenia z 2018 r. instrukcja archiwalna składa się z dwunastu rozdziałów uwzględniających opis organizacji archiwum bieżącego oraz czynności wykonywanych przez archiwistów zakładowych. Są to: 1. Przepisy ogólne, 2. Organizacja i zadania archiwum, 3. Personel archiwum, 4. Lokal i wyposażenie archiwum, 5. Przejmowanie dokumentacji przez archiwum, 6. Przechowywanie i zabezpieczenie dokumentacji oraz prowadzenie jej ewidencji, 7. Skontrum, 8. Udostępnianie dokumentacji przechowywanej w archiwum, 9. Wycofywanie dokumentacji ze stanu archiwum, 10. Brakowanie dokumentacji niearchiwalnej, 11. Przekazywanie materiałów archiwalnych do archiwum państwowego i archiwum wyodrębnionego, 12. Sprawozdawczość archiwum ${ }^{36}$. Dla porównania warto przedstawić budowę instrukcji z 1985 r. (która też nie odbiega znacząco od konstrukcji przyjętej dla tego typu normatywów). Pierwsza część dotyczy organizacji archiwum, a druga jego funkcjonowania. Omawiana instrukcja składa się z dziesięciu rozdziałów: 1. Przepisy ogólne, 2. Podział

${ }^{32}$ Zestawienie instytucji wdrażających system EZD PUW na podstawie porozumienia z wojewodą podlaskim zob.: Elektroniczne Zarządzanie Dokumentacją. Partnerzy, https://ezd.gov.pl/www/ezd/ partnerzy [dostęp: 2.06.2020].

${ }^{33}$ Ustawa z dnia 27 lipca 2001 r...., art. 53 § 1. Zob. także: Dokumentacja elektroniczna w podmiotach publicznych, red. G. Szpor, Warszawa 2013, s. 19.

${ }^{34}$ Ustawa z dnia 27 lipca 2001 r. Prawo o ustroju sądów ..., § 559.5.

${ }^{35}$ Zob. np.: Instrukcja kancelaryjna Sądu Okręgowego w Białymstoku, http://bialystok.so.gov.pl/ component/attachments/download/387.html [dostęp: 8.06.2020]. Sąd Okręgowy w Białymstoku jest jednostką, która zdecydowała się na wdrożenie systemu EZD PUW.

${ }^{36}$ Instrukcja archiwalna z $2018 \mathrm{r}$. 
zasobu archiwum zakładowego na kategorie, 3. Personel archiwum zakładowego i zakres jego obowiązków, 4. Lokal i wyposażenie archiwum zakładowego, 5. Przejmowanie dokumentacji przez archiwum zakładowe na przechowanie, 6. Przechowywanie i ewidencja zasobu archiwum zakładowego, 7. Korzystanie $\mathrm{z}$ dokumentacji przechowywanej w archiwum zakładowym, 8. Brakowanie akt, 9. Przekazywanie materiałów archiwalnych do archiwum państwowego, 10. Przepisy końcowe ${ }^{37}$.

Konfrontując dwie instrukcje archiwalne, od razu można zauważyć, że w 2018 r. pojawił się słownik terminologiczny, a zadania archiwum zakładowego zostały precyzyjniej sformułowane. Szczególnie cieszy zapis mówiący, że do zadań archiwum należy (m.in.) ,,doradzanie komórkom organizacyjnym w zakresie właściwego postępowania z dokumentacją" i ,udzielanie komórkom organizacyjnym informacji o zasadach porządkowania dokumentacji innej niż $\mathrm{w}$ postaci elektronicznej w systemie teleinformatycznym podlegającej przekazaniu do archiwum" ${ }^{38}$. Brak jest rozdziału dotyczącego podziału zasobu archiwum, ale za to są części poświęcone skontrum, wycofywaniu dokumentacji ze stanu archiwum oraz sprawozdawczości. Kilka wątków zasługuje na szczegółowe omówienie:

\section{Organizacja archiwum}

Zarządzenie zezwala na zorganizowanie archiwum wielozakładowego, nazwanego w akcie prawnym międzyzakładowym, dla niektórych bądź wszystkich jednostek organizacyjnych, mających siedzibę w tej samej miejscowości ${ }^{39}$. Taki zapis ma być jedynie usankcjonowaniem istnienia tego typu komórek organizacyjnych, o czym świadczy treść § 7. Jest on zresztą powtórzeniem możliwości wynikającej z zapisu §3. instrukcji z 1985 r. Takie rozwiązanie organizacyjne - choć wydaje się słuszne $z$ ekonomicznego punktu widzenia - jest niezgodne z zapisem ustawy o narodowym zasobie archiwalnym i archiwach $^{40}$. Trzeba też pamiętać, że w tych wypadkach instrukcja nakazuje prowadzenie odrębnej ewidencji (w odniesieniu do dokumentacji przekazanej przez każdą z jednostek organizacyjnych ${ }^{41}$. Nadzór nad realizacją przepisów zarządzenia sprawuje kierownik jednostki organizacyjnej, zaś nadzór merytoryczny nad działalnością

\footnotetext{
${ }^{37}$ Instrukcja archiwalna z $1985 \mathrm{r}$.

${ }^{38}$ Instrukcja archiwalna z 2018 r., § 4.1-4.2.

39 Zarządzenie Ministra Sprawiedliwości z dnia 14 grudnia 2018 r..., $\$ 2.2$.

${ }^{40}$ Ustawa z dnia 14 lipca 1983 r...., art. 33, 35.1., 36a. W 2007 r. dopuszczono możliwość organizowania $\mathrm{w}$ instytucjach więcej niż jednego archiwum zakładowego; zob.: M. Konstankiewicz, Ksztaltowanie podstaw prawnych dziatalności archiwalnej w Polsce na przełomie XX i XXI w., „Archeion" 2019, t. 120, s. 345.

${ }^{41}$ Instrukcja archiwalna z 2018 r., § 13.4. W instrukcji archiwalnej z 1985 r. przyjęto podział podmiotowy zgromadzonej dokumentacji, wydzielając dla każdej z tych jednostek część pomieszczeń i prowadząc dla nich odrębną ewidencję; zob.: instrukcja archiwalna z 1985 r., § 3.2.
} 
archiwum zakładowego powierzony został dyrektorowi właściwego archiwum państwowego ${ }^{42}$.

Instrukcja sugeruje przyjęcie dodatkowego normatywu regulującego pracę archiwum zakładowego, a mianowicie wewnętrznego regulaminu organizacji pracy, o czym ma zadecydować kierownik jednostki organizacyjnej. Także $\mathrm{w}$ jego kompetencji jest umiejscowienie archiwum w strukturze wspomnianej jednostki ${ }^{43}$, choć ten zapis nie jest do końca jasny. Ust. $1 \S 3$ stanowi bowiem, że miejsce to określa kierownik jednostki organizacyjnej, zaś ust. 5 określa, że w jednostkach organizacyjnych sądownictwa powszechnego i sądownictwa wojskowego umiejscowienie archiwum określone jest w przepisach odrębnych. Zatem zapis ust. 1 należy traktować prawdopodobnie jako dotyczący innych, niż wskazane w ustępie trzecim, jednostek (m.in. inspektoratów służby więziennej, aresztów śledczych, ośrodków kuratorskich).

$\mathrm{W}$ instrukcji zrezygnowano z zapisu poświęconego kwestii wykształcenia personelu archiwalnego, co należy uznać za błąd (w instrukcji z 1985 r. jest zapis o ukończonym policealnym studium $\mathrm{z}$ archiwistyki lub wykształceniu średnim z ukończonym kursem archiwalnym). Brak tych wytycznych spowodować może, że do archiwum zakładowego trafi osoba bez jakiegokolwiek przygotowania do pracy w tej komórce organizacyjnej. Sporo miejsca poświęcono za to protokołowi przekazania obowiązków nowemu pracownikowi archiwum.

\section{Ksztaltowanie narastającego zasobu archiwalnego}

Z punktu widzenia kształtowania narastającego zasobu archiwalnego niezwykle istotny jest klarowny zapis $\S 1.2$. instrukcji archiwalnej, który stanowi, że „dokumentacja przed przekazaniem do archiwum powinna być uporządkowana i zakwalifikowana do właściwych kategorii archiwalnych" ${ }^{\text {". }}$. Dotyczy to zarówno akt spraw sądowych, jak i dokumentacji związanej z organizacją i funkcjonowaniem instytucji wymiaru sprawiedliwości, zwanej w zarządzeniu w sprawie sekretariatów sądowych dokumentacją spraw z zakresu administracji i nadzoru ${ }^{45}$. W wypadku akt spraw sądowych rolę kwalifikatora akt pełni wspomniane już rozporządzenie z 2004 r. dotyczące przechowywania tego rodzaju dokumentacji. W § 1. sprecyzowano, że rozporządzenie „określa warunki i zakres przechowywania akt w sądzie przez okres niezbędny ze względu na rodzaj i charakter spraw, terminy przedawnienia, interesy osób biorących udział w postępowaniu i znaczenie materiałów zawartych $\mathrm{w}$ aktach jako źródła informacji oraz warunki i tryb przechowywania i przekazywania akt archiwom państwowym, a także wa-

\footnotetext{
${ }^{42}$ Zarządzenie Ministra Sprawiedliwości z dnia 14 grudnia 2018 r..., § 3-4.

${ }^{43}$ Instrukcja archiwalna z 2018 r., § 3.1. i 3.3.

${ }^{44}$ Ibidem, $§ 1.2$.

${ }^{45}$ Zarządzenie Ministra Sprawiedliwości z dnia 19 czerwca 2019 r...., § 544.
} 
runki i tryb niszczenia akt po upływie okresu ich przechowywania"46. Kwalifikacja archiwalna została określona $\mathrm{z}$ uwzględnieniem podziału rzeczowego akt na: sprawy karne, o wykroczenia, cywilne i gospodarcze, rozpoznawane w sądach rodzinnych, z zakresu prawa pracy i ubezpieczeń społecznych. W oddzielnym rozdziale unormowano okresy przechowywania ksiąg i urządzeń ewidencyjnych w sprawach sądowych ${ }^{47}$. Poza kwalifikacją archiwalną, akt prawny zawiera istotny zapis, często nieprzestrzegany w praktyce sądowej, postanawiający, że nadawanie kategorii archiwalnej, wraz ze wskazaniem okresu przechowywania, należy do obowiązków przewodniczącego rozprawy lub posiedzenia, którą to czynność należy wykonać po zakończeniu postępowania sądowego. Do tego ważnego zadania prezes sądu może wyznaczyć referendarza sądowego, asystenta sędziego lub - w wyjątkowych przypadkach - kierownika sekretariatu ${ }^{48}$. Ciekawe rozwiązanie (nie zawsze komentowane pozytywnie) dotyczy kwalifikowania do kategorii A dokumentacji jednej sprawy typowej z okresu pięcioletniego z każdego rozdziału części szczególnej kodeksu karnego, kodeksu wykroczeń, oraz z poszczególnych rodzajów spraw przewidzianych w wykazie spraw cywilnych, spraw z zakresu prawa pracy i ubezpieczeń społecznych oraz z ustaw szczególnych. Z kolei dla spraw z zakresu administracji i nadzoru każda jednostka organizacyjna wprowadza jednolity rzeczowy wykaz akt ${ }^{49}$. Treść $\S \S 544-558$ zarządzenia $\mathrm{w}$ sprawie sekretariatów sądowych świadczy o tym, że za nadanie kategorii archiwalnej oraz wskazanie okresu przechowywania akt odpowiedzialny jest referent załatwiający sprawę. Zapis ten powinien być potwierdzony w instrukcji kancelaryjnej ${ }^{50}$.

\section{Elektroniczne archiwum}

Instrukcja archiwalna przewiduje korzystanie z informatycznych narzędzi do zarządzania dokumentacją w archiwum. Mają one służyć przede wszystkim ewidencjonowaniu właściwie wszystkich aspektów działalności archiwum: przejmowania, przechowywania, udostępniania, brakowania dokumentacji niearchiwalnej i przekazywania materiałów archiwalnych do archiwów państwowych. Narzędzia te wykorzystuje się do obsługi tylko tej dokumentacji, której czynności kancelaryjne oraz ich dokumentowanie nie są wykonywane w ramach EZD ${ }^{51}$. $\mathrm{Z}$ kolei dla dokumentacji w postaci elektronicznej w systemie teleinformatycz-

\footnotetext{
${ }^{46}$ Rozporządzenie Ministra Sprawiedliwości z dnia 5 marca 2004 r...., 1.

${ }^{47}$ Uzupełnieniem treści dotyczącej kwalifikacji akt jest rozdział zatytułowany „Przepisy przejściowe i końcowe".

${ }^{48}$ Rozporządzenie Ministra Sprawiedliwości z dnia 5 marca 2004 r...., § 26.1 i 26.1a. Zobacz także $\S 26.2$.

49 Zarządzenie Ministra Sprawiedliwości z dnia 19 czerwca 2019 r...., 544.

${ }^{50}$ Ibidem, § 566-567.

${ }^{51}$ Instrukcja archiwalna z 2018 r., $§ 2.1$.
} 
nym, w ramach którego realizowane jest EZD, instrukcja archiwalna uwzględnia istnienie archiwum bieżącego, funkcjonującego w dwóch wariantach: 1) funkcję archiwum spełnia system, 2) funkcję archiwum spełnia moduł tego systemu ${ }^{52}$. Także to rozwiązanie jest odzwierciedleniem zapisu wspomnianego już zarządzenia Prezesa Rady Ministrów z 18 stycznia 2011 r. Zatem przekazanie dokumentacji elektronicznej do archiwum elektronicznego polega na przekazaniu uprawnień do tej dokumentacji innej osobie.

Przy omawianiu wątku archiwum elektronicznego na uwagę zasługuje także zapis $\S 24$ b. rozporządzenia z 5 marca 2004 r., dotyczący elektronicznego postępowania upominawczego. Stanowi on, że w odniesieniu do akt spraw rozpoznawanych w tego typu postępowaniu oraz tytułów wykonawczych obejmujących orzeczenia wydane w tym postępowaniu, funkcję archiwum zakładowego spełnia system teleinformatyczny ${ }^{53}$. Zarówno elektroniczne repertorium, jak i inne urządzenie ewidencyjne, łącznie z metadanymi, należy przechowywać w sposób zapewniający bezpieczeństwo i integralność ich treści oraz możliwość wyodrębnienia metadanych ${ }^{54}$. Rozporządzenie z 2004 r. definiuje metadane analogicznie do rozporządzenia Ministra Spraw Wewnętrznych i Administracji z dnia 30 października 2006 r. w sprawie niezbędnych elementów struktury dokumentów elektronicznych, wskazując, że przez metadane rozumie się zestaw logicznie powiązanych z elektronicznym repertorium lub innym urządzeniem ewidencyjnym i usystematyzowanych informacji opisujących to repertorium lub urządzenie, ułatwiających jego wyszukiwanie, kontrolę, zrozumienie i długotrwałe przechowywanie oraz zarządzanie nim. Są to: identyfikator, twórca, tytuł, data, format, dostęp, typ, relacja, grupowanie, kwalifikacja, język, opis, uprawnienia ${ }^{55}$.

Inna sprawa to przechowywanie protokołów rejestrujących dźwięk albo obraz i dźwięk z przebiegu posiedzenia jawnego w postępowaniu cywilnym. Zgodnie z rozporządzeniem z 2 marca 2015 r. utrwalony zapis wraz z metadanymi należy przechowywać w systemie teleinformatycznym, zapewniając ich poufność, integralność, a także ochronę przed utratą lub zniszczeniem ${ }^{56}$. Jednocześnie $\mathrm{z}$ rozporządzenia z 2004 r. dowiadujemy się, że dopuszcza się zniszczenie zapisu obrazu bez zgody dyrektora właściwego terytorialnie archiwum państwowego w sytuacji, gdy sporządzono protokół posiedzenia jawnego za pomocą urządzenia rejestrującego obraz i dźwięk. Kolejnym warunkiem jest uprawomocnienie się orzeczenia kończącego postępowanie w sprawie. W wypadku sprawy, której przysługuje skarga kasacyjna, jest to możliwe po upływie terminu do jej wniesienia, a jeśli skarga została złożona, to po zakończeniu postępowania wywoła-

\footnotetext{
${ }^{52}$ Ibidem, $\S 3.2$.

${ }^{53}$ Rozporządzenie Ministra Sprawiedliwości z dnia 5 marca 2004 r...., § 24b; Dokumentacja elektroniczna..., s. 20.

${ }^{54}$ Rozporządzenie Ministra Sprawiedliwości z dnia 5 marca 2004 r...., § 24a ust. 1.

55 Ibidem, § 24a ust. 2-3; Dokumentacja elektroniczna..., s. 20.

${ }^{56}$ Rozporządzenie Ministra Sprawiedliwości z dnia 20 marca 2015 r...., 11.
} 
nego jej wniesieniem. W takim wypadku pozostawia się w systemie teleinformatycznym wyłącznie zapis dźwięku. Zniszczenie to nie może być dokonane w sytuacji, gdy akta sprawy zaliczono do kategorii $\mathrm{A}^{57}$.

Rozporządzenie z 2017 r. dotyczące utrwalania obrazu lub dźwięku dla celów procesowych w postępowaniu karnym zakłada, że służyć do tego mogą urządzenia i środki techniczne, w tym systemy teleinformatyczne, utrwalające zapis na nośnikach analogowych lub informatycznych nośnikach danych. Nośniki muszą umożliwić przechowywanie danych przez okres niezbędny do prawidłowego przeprowadzenia postępowania karnego. W rozporządzeniu znajdziemy także wytyczne dotyczące warunków, jakie muszą być spełnione przez system teleinformatyczny (w tym m.in. możliwość przekazania zapisów stanowiących materiały archiwalne do archiwów państwowych) ${ }^{58}$. Znane już w sądach powszechnych Centralne Archiwum Protokołów Elektronicznych (CAPE) to rozwiązanie składające się z komponentów sprzętowych i programowych odpowiedzialnych za zarządzanie archiwum oraz przechowywanie danych. Wśród głównych usług świadczonych przez CAPE wymienia się bezpieczne przechowywanie danych przez okres przewidziany $\mathrm{w}$ przepisach prawa, wyszukiwanie i udostępnianie tego rodzaju dokumentacji, także w zakresie określonym przez akty prawa czy generowanie raportó $\mathrm{w}^{59}$. Zgromadzone $\mathrm{w}$ ten sposób materiały archiwalne docelowo trafiać będą do archiwum wieczystego ${ }^{60}$.

Jak już wspomniano, system teleinformatyczny spełnia funkcję archiwum zakładowego. W sytuacji braku odrębnych przepisów regulujących postępowanie $\mathrm{z}$ dokumentacją elektroniczną (np. wybranych rejestrów elektronicznych) należy stosować przepisy rozporządzeń ministra spraw wewnętrznych i administracji z 2006 r. $^{61}$

57 Rozporządzenie Ministra Sprawiedliwości z dnia 5 marca 2004 r...., § 29.

58 Rozporządzenie Ministra Sprawiedliwości z dnia 11 stycznia 2017 r...., § 3. Podobne rozwiązania dotyczące rejestracji dźwięku i obrazu rozprawy sądowej wprowadzono m.in. w Wielkiej Brytanii, zob. D. Drzewiecka, Dokumentacja rozpraw sądowych Sądu Najwyższego Zjednoczonego Królestwa Wielkiej Brytanii i Irlandii Pólnocnej [w:] Belliculum diplomaticum VI Thorunense. Od dyplomatyki i archiwistyki do dokumentu elektronicznego, red. K. Kopiński i J. Tandecki, Toruń 2016, s. 207-216.

${ }^{59}$ Opis przedmiotu zamówienia - załącznik nr 2 do umowy na dostawę i wdrożenie systemu cyfrowej rejestracji przebiegu rozpraw sądowych w Sądzie Okręgowym w Toruniu, s. 9, https://www. torun.so.gov.pl/download/5.-rejestracja-sal-rozpraw---opz-(zal.-2-do-umowy)-1570516661.pdf [dostęp: 2.12 .2020$]$.

${ }^{60} \mathrm{~W}$ tym miejscu warto zasygnalizować postępy w procesie tworzenia Archiwum Dokumentów Elektronicznych - systemu, do którego docelowo trafią także tego typu materiały archiwalne.

${ }^{61}$ Rozporządzenie Ministra Spraw Wewnętrznych i Administracji z dnia 30 października $2006 \mathrm{r}$. w sprawie niezbędnych elementów struktury dokumentów elektronicznych (Dz.U. 2006, nr 206, poz. 1517; rozporządzenie Ministra Spraw Wewnętrznych i Administracji z dnia 30 października 2006 r. w sprawie szczegółowego sposobu postępowania z dokumentami elektronicznymi, (Dz.U. 2006, nr 206, poz. 1518); rozporządzenie Ministra Spraw Wewnętrznych i Administracji z dnia 2 listopada 2006 r. w sprawie wymagań technicznych formatów zapisu i informatycznych nośników 
Poza instrukcjami archiwalnymi, kolejnym ważnym dla archiwisty zatrudnionego $\mathrm{w}$ archiwum sądu powszechnego aktem prawnym jest wielokrotnie już wspominane rozporządzenie z 5 marca 2004 r. Oprócz omówionych wyżej wątków, dokładniejszego omówienia wymaga sama konstrukcja aktu, na którą składa się dziewięć rozdziałów: 1. Przepisy ogólne; 2. Okresy przechowywania akt spraw karnych; 3. Okresy przechowywania akt spraw o wykroczenia; 4. Okresy przechowywania akt spraw cywilnych i gospodarczych; 5. Okresy przechowywania akt spraw rozpoznawanych w sądach rodzinnych; 6 . Okresy przechowywania akt spraw z zakresu prawa pracy i ubezpieczeń społecznych; 7. Okresy przechowywania ksiąg i urządzeń ewidencyjnych w sprawach sądowych; 8. Warunki i tryb przechowywania, niszczenia oraz przekazywania archiwom państwowym akt spraw sądowych; 9. Przepisy przejściowe i końcowe ${ }^{62}$. Już same tytuły rozdziałów sugerują, że mamy do czynienia z aktem wyjątkowym. $Z$ jednej strony pełni on rolę kwalifikatora archiwalnego, określając okresy przechowywania akt spraw sądowych, ksiąg i urządzeń ewidencyjnych. $Z$ drugiej strony reguluje sprawy, które zazwyczaj unormowane są w instrukcjach archiwalnych. Podobny charakter mają wspomniane wcześniej rozporządzenie z 14 lutego 2000 r. oraz zarządzenie z 25 lipca $1995 \mathrm{r}$.

Rekapitulując, należy stwierdzić, że resort sprawiedliwości w Polsce i instytucje mu podległe są aktualnie $\mathrm{w}$ trakcie stale postępującej informatyzacji. Sporo rozwiązań informatycznych zostało z powodzeniem zrealizowanych, jak np. elektroniczne księgi wieczyste, krajowy rejestr karny, czy elektroniczne postępowanie upominawcze. O rozmiarze przedsięwzięcia świadczą chociażby zapisy zarządzenia Ministra Sprawiedliwości z dnia 28 grudnia 2018 r. w sprawie powierzenia sądom apelacyjnym wykonywania czynności związanych z projektowaniem, wdrażaniem i utrzymywaniem systemów informatycznych ${ }^{63}$. Pozytywnie należy ocenić fakt ukazania się nowej, chciałoby się powiedzieć nowoczesnej, instrukcji o organizacji i zakresie działania archiwów zakładowych, choć na jej temat archiwiści nie zawsze wypowiadają się pozytywnie, zarzucając jej brak uregulowania wszystkich niezbędnych kwestii, zbyt dużą zbieżność treści z rozporządzeniem z dnia 18 stycznia $2011 \mathrm{r}$. oraz brak spójności z bieżącą sytuacją w archiwach sądowych ${ }^{64}$. Z całą pewnością część ważnych wątków powinna być dopracowana. Wówczas instrukcja archiwalna sądów mogłaby spełniać warunki wynikające $\mathrm{z}$ definicji instrukcji archiwalnej.

\footnotetext{
danych, na których utrwalono materiały archiwalne przekazywane do archiwów państwowych (Dz.U. 2006, nr 206, poz. 1519).

${ }_{62}$ Rozporządzenie Ministra Sprawiedliwości z dnia 5 marca 2004 r., op.cit.

${ }^{63}$ Zarządzenie Ministra Sprawiedliwości z dnia 28 grudnia 2018 r. w sprawie powierzenia sądom apelacyjnym wykonywania czynności związanych z projektowaniem, wdrażaniem i utrzymywaniem systemów informatycznych (Dz. Urz. Ministra Sprawiedliwości 2018, poz. 352).

${ }^{64}$ Stowarzyszenie „Archiwizjoner”, https://web.facebook.com/archiwizjoner/ [dostęp: 15.02.2019].
} 
Rozważania niniejsze pokazują, że sądy powszechne w Polsce są jednostkami wyjątkowymi w zakresie zarządzania dokumentacją w archiwach zakładowych (choć także i na przedpolu archiwalnym dalszym). Świadczą o tym przedstawione tu akty prawne, w tym normatywne. Ich liczba, wynikająca z różnorodności załatwianych spraw oraz masowości wytwarzanej przez te jednostki dokumentacji, pozwala twierdzić, że praca w sądowym archiwum zakładowym wymaga ciągłego rozwoju, a przynajmniej aktualizacji zdobytej wiedzy. Niestety, nawet w wypadku bieżącego śledzenia i starannego przestrzegania zmieniających się przepisów, często bywa także skomplikowana, szczególnie wtedy, gdy przepisy te nie regulują precyzyjnie wszystkich istotnych kwestii pozwalających na sprawne zarządzanie dokumentacją i rozwiązywanie pojawiających się $\mathrm{w}$ jego trakcie problemów.

\section{Źródla}

Ustawa z dnia 14 lipca 1983 r. o narodowym zasobie archiwalnym i archiwach (t.j.: Dz.U. 2020, poz. 164).

Ustawa z dnia 27 lipca 2001 r. Prawo o ustroju sądów powszechnych (Dz.U. 2020, poz. 365).

Rozporządzenie Ministra Sprawiedliwości z dnia 19 listopada 1936 r. o niszczeniu odpisów protestów weksli i czeków (Dz.U. 1936, nr 90 poz. 625).

Rozporządzenie Ministra Sprawiedliwości z dnia 14 lipca 1986 r. w sprawie prowadzenia ksiąg wieczystych założonych przed 01.01 .1947 r. oraz utraty mocy prawnej niektórych takich ksiąg (Dz.U. 1986, nr 28, poz. 141).

Rozporządzenie Ministra Sprawiedliwości z dnia 6 grudnia 1975 r. w sprawie okresów przechowywania i warunków niszczenia akt spraw sądowych lub przekazywania ich archiwom państwowym (Dz.U. 1975, nr 43, poz. 220).

Rozporządzenie Ministra Sprawiedliwości z dnia 5 maja 1989 r. w sprawie okresów przechowywania i warunków niszczenia akt spraw sądowych lub przekazywania ich archiwom państwowym (Dz.U. 1989, nr 28, poz. 150).

Rozporządzenie Ministra Sprawiedliwości z dnia 12 kwietnia 1991 r. w sprawie prowadzenia ksiąg notarialnych oraz przekazywania na przechowanie dokumentów sądom rejonowym (t.j.: Dz.U. 2018, poz. 2039).

Rozporządzenie Ministra Sprawiedliwości z dnia 11 czerwca 1999 r. zmieniające rozporządzenie w sprawie okresów przechowywania i warunków niszczenia akt spraw sądowych lub przekazywania ich archiwom państwowym (Dz.U. 1999, nr 57, poz. 602).

Rozporządzenie Ministra Sprawiedliwości z dnia 14 lutego 2000 r. w sprawie ustalenia warunków i okresów czasu, po których akta spraw o wykroczenia podlegają zniszczeniu w całości lub w części albo przekazaniu archiwom państwowym (Dz.U. 2000, nr 12, poz. 148).

Rozporządzenie Ministra Sprawiedliwości z dnia 21 grudnia 2000 r. w sprawie sposobu przekazywania dotychczasowych rejestrów i przekazywania akt rejestrowych oraz wydawania z nich wypisów, wyciągów i zaświadczeń (Dz.U. 2000, nr 117, poz. 1239). 
Rozporządzenie Ministra Sprawiedliwości z dnia 17 września 2001 r. w sprawie prowadzenia ksiąg wieczystych i zbiorów dokumentów (Dz.U. 2001, nr 102, poz. 1122).

Rozporządzenie Ministra Sprawiedliwości z dnia 18 czerwca 2003 r. w sprawie postępowania o zachowanie w tajemnicy okoliczności umożliwiających ujawnienie tożsamości świadka oraz sposobu postępowania z protokołami z zeznań tego świadka (t.j.: Dz.U. 2019, poz. 110).

Rozporządzenie Ministra Sprawiedliwości z dnia 5 marca 2004 r. w sprawie przechowywania akt spraw sądowych oraz ich przekazywania do archiwów państwowych lub do zniszczenia (Dz.U. 2004, nr 46, poz. 443, t.j.: Dz.U. 2014, poz. 991).

Rozporządzenie Ministra Spraw Wewnętrznych i Administracji z dnia 30 października 2006 r. w sprawie niezbędnych elementów struktury dokumentów elektronicznych (Dz.U. 2006, nr 206, poz. 1517).

Rozporządzenie Ministra Spraw Wewnętrznych i Administracji z dnia 30 października 2006 r. w sprawie szczegółowego sposobu postępowania z dokumentami elektronicznymi (Dz.U. 2006, nr 206, poz. 1518).

Rozporządzenie Ministra Spraw Wewnętrznych i Administracji z dnia 2 listopada 2006 r. w sprawie wymagań technicznych formatów zapisu i informatycznych nośników danych, na których utrwalono materiały archiwalne przekazywane do archiwów państwowych (Dz.U. 2006, nr 206, poz. 1519).

Rozporządzenie Prezesa Rady Ministrów z dnia 18 stycznia 2011 r. w sprawie instrukcji kancelaryjnej, jednolitych rzeczowych wykazów akt oraz instrukcji w sprawie organizacji i zakresu działania archiwów zakładowych (Dz.U. 2011, nr 14, poz. 67).

Rozporządzenie Ministra Sprawiedliwości z dnia 10 sierpnia 2011 r. w sprawie zapisu dźwięku albo obrazu i dźwięku z przebiegu posiedzenia jawnego (Dz.U. 2011, nr 175, poz. 1046).

Rozporządzenie Ministra Sprawiedliwości z dnia 7 października 2011 r. w sprawie przechowywania akt spraw komorniczych oraz zamkniętych urządzeń ewidencyjnych (Dz.U. 2016, poz. 370).

Rozporządzenie Ministra Sprawiedliwości z dnia 2 grudnia 2011 r. zmieniające rozporządzenie w sprawie archiwizowania akt spraw sądowych (Dz.U. 2011, nr 274, poz. 1623).

Rozporządzenie Ministra Sprawiedliwości z dnia 20 lutego 2012 r. w sprawie sposobu postępowania z protokołami przesłuchań i innymi dokumentami lub przedmiotami, na które rozciąga się obowiązek zachowania $\mathrm{w}$ tajemnicy informacji niejawnych albo zachowania tajemnicy związanej z wykonywaniem zawodu lub funkcji (Dz.U. 2012, poz. 219).

Rozporządzenie Ministra Sprawiedliwości z dnia 5 kwietnia 2013 r. zmieniające rozporządzenie w sprawie przechowywania akt spraw sądowych oraz ich przekazywania do archiwów państwowych lub do zniszczenia (Dz.U. 2013, poz. 469).

Rozporządzenie Ministra Sprawiedliwości z dnia 21 listopada 2013 r. w sprawie prowadzenia zbioru dokumentów dla nieruchomości, które nie mają założonych ksiąg wieczystych albo których księgi wieczyste zaginęły lub uległy zniszczeniu, oraz postępowania w tych sprawach (Dz.U. 2013, poz. 1397).

Rozporządzenie Ministra Sprawiedliwości z dnia 20 marca 2015 r. w sprawie zapisu dźwięku albo obrazu i dźwięku z przebiegu posiedzenia jawnego w postępowaniu cywilnym (Dz.U. 2015, poz. 359). 
Rozporządzenie Ministra Sprawiedliwości z dnia 23 grudnia 2015 r. w sprawie utrwalania dźwięku albo obrazu i dźwięku dla celów procesowych w postępowaniu karnym (Dz.U. 2015, poz. 2344).

Rozporządzenie Ministra Sprawiedliwości z dnia 10 października 2016 r. zmieniające rozporządzenie w sprawie zapisu dźwięku albo obrazu i dźwięku z przebiegu posiedzenia jawnego w postępowaniu cywilnym (Dz.U. 2016, poz. 1697).

Rozporządzenie Ministra Sprawiedliwości z dnia 11 stycznia 2017 r. w sprawie utrwalania obrazu lub dźwięku dla celów procesowych w postępowaniu karnym (Dz.U. 2017, poz. 93).

Rozporządzenie Ministra Sprawiedliwości z dnia 29 listopada 2019 r. zmieniające rozporządzenie w sprawie przechowywania akt spraw sądowych oraz ich przekazywania do archiwów państwowych lub do zniszczenia (Dz.U. 2019, poz. 2396).

Obwieszczenie Ministra Sprawiedliwości z dnia 7 lutego 2020 r. w sprawie wykazu jednostek podległych Ministrowi Sprawiedliwości lub przez niego nadzorowanych (M.P. 2020, poz. 241).

Zarządzenie Ministra Sprawiedliwości z dnia 27 kwietnia 1983 r. w sprawie biurowości sądów wojewódzkich i rejonowych (instrukcja sądowa) (Dz. Urz. Ministra Sprawiedliwości 1983, nr 4, poz. 20, z późn. zm.).

Zarządzenie Ministra Sprawiedliwości z dnia 30 grudnia 1985 r. w sprawie archiwów zakładowych w jednostkach organizacyjnych resortu sprawiedliwości. Załącznik do zarządzenia: Instrukcja w sprawie organizacji i zakresu działania archiwów zakładowych w resorcie sprawiedliwości (Dz. Urz. Ministra Sprawiedliwości 1985, nr 8, poz. 55).

Zarządzenia Ministra Sprawiedliwości dnia 22 lutego 1988 r. w sprawie organizacji i zakresu działania sekretariatów sądowych oraz innych działów administracji sądowej (Dz. Urz. Ministra Sprawiedliwości 1988, nr 2, poz. 6, z późn. zm.).

Zarządzenie Ministra Sprawiedliwości z dnia 25 lipca 1995 r. w sprawie kwalifikacji do materiałów archiwalnych lub dokumentacji niearchiwalnej akt i ksiąg kolegiów do spraw wykroczeń z lat 1981-1989, okresów ich przechowywania oraz warunków niszczenia lub przekazywania archiwom państwowym (Dz. Urz. Ministra Sprawiedliwości, nr 3, poz. 19).

Zarządzenie Ministra Sprawiedliwości dnia 12 grudnia 2003 r. w sprawie organizacji i zakresu działania sekretariatów sądowych oraz innych działów administracji sądowej (Dz. Urz. Ministra Sprawiedliwości 2003, nr 5, poz. 22, z późn. zm.).

Zarządzenie Ministra Sprawiedliwości z dnia 14 grudnia 2018 r. w sprawie instrukcji w sprawie organizacji i zakresu działania archiwów zakładowych w jednostkach organizacyjnych podległych Ministrowi Sprawiedliwości lub przez niego nadzorowanych. Załącznik do zarządzenia: Instrukcja w sprawie organizacji i zakresu działania archiwów zakładowych w jednostkach organizacyjnych podległych Ministrowi Sprawiedliwości lub przez niego nadzorowanych (Dz. Urz. Ministra Sprawiedliwości 2018, poz. 348).

Zarządzenie Ministra Sprawiedliwości z dnia 28 grudnia 2018 r. w sprawie powierzenia sądom apelacyjnym wykonywania czynności związanych z projektowaniem, wdrażaniem i utrzymywaniem systemów informatycznych (Dz. Urz. Ministra Sprawiedliwości 2018, poz. 352).

Zarządzenie Ministra Sprawiedliwości z dnia 19 czerwca 2019 r. w sprawie organizacji i zakresu działania sekretariatów sądowych oraz innych działów administracji sądowej (Dz. Urz. Ministra Sprawiedliwości 2019, poz. 138). 
Załącznik nr 1 do zarządzenia Nr A-0220-1/17 Prezesa Sądu Okręgowego w Białymstoku z dnia 9 stycznia 2017 r. - Instrukcja kancelaryjna Sądu Okręgowego w Białymstoku, http://bialystok. so.gov.pl/component/attachments/download/387.html [dostęp: 8.06.2020].

Opis przedmiotu zamówienia - załącznik nr 2 do umowy na dostawę i wdrożenie systemu cyfrowej rejestracji przebiegu rozpraw sądowych w Sądzie Okręgowym w Toruniu, s. 9, https://www. torun.so.gov.pl/download/5.-rejestracja-sal-rozpraw---opz-(zal.-2-do-umowy)-1570516661. pdf [dostęp: 2.12.2020].

\section{Bibliografia}

Archiwa instytucji wymiaru sprawiedliwości w shużbie państwa i obywateli. Materiały III Krajowego Sympozjum Archiwalnego Łódź, 4-5 września 2001 r., red. J. Baranowski i U. Zarzycka-Sutter, Łódź 2001.

Archiwa Państwowe. Zarządzanie dokumentacją. Instrukcje i wykazy akt, https://www.archiwa. gov.pl/pl/zarzadzanie-dokumentacja/zarz $\% \mathrm{C} 4 \% 85$ dzanie-dokumentacj\%C4\%85/instrukcje-iwykazy-akt/przyk\%C5\%82adowe-instrukcje-kancelaryjne-i-archiwalne [dostęp: 1.06.2020].

Dokumentacja elektroniczna w podmiotach publicznych, red. G. Szpor, Warszawa 2013.

Drzewiecka D., Dokumentacja rozpraw sądowych Sąu Najwyższego Zjednoczonego Królestwa Wielkiej Brytanii i Irlandii Pótnocnej [w:] Belliculum diplomaticum VI Thorunense. Od dyplomatyki i archiwistyki do dokumentu elektronicznego, red. K. Kopiński i J. Tandecki, Toruń 2016, s. 207-216.

Elektroniczne Zarządzanie Dokumentacją. Partnerzy, https://ezd.gov.pl/www/ezd/partnerzy [dostęp: 2.06.2020].

Fischer I., Przekazywanie materiatów archiwalnych do archiwów państwowych w świetle aktualnych przepisów, http://www.saws.pl/asp/pl start.asp?typ=14\&menu=42\&strona=1 [dostęp: 2.12.2020].

Konstankiewicz M., Kształtowanie podstaw prawnych działalności archiwalnej w Polsce na przetomie XX i XXI w., „Archeion” 2019, t. 120, s. 337-366.

Konstankiewicz M., Regulacje dotyczace udostepniania dokumentacji przez archiwa instytucji wymiaru sprawiedliwości, http://www.saws.pl/asp/pl_start.asp?typ $=14 \&$ menu=42\&strona $=1$ [dostęp: 2.12.2020].

Kotecka S., Dokument elektroniczny w wymiarze sprawiedliwości - stan obecny, [w:] Materiaty pokonferencyjne Wroctaw 2012-2013, praca zbior., Wrocław 2013, s. 2-17.

Kotecka S., Repertoria, rejestry, protokoły i załaczniki elektroniczne do akt - problemy z archiwizacja, [w:] Materiaty pokonferencyjne Wrocław 2012-2013, praca zbior., Wrocław 2013, s. $145-152$.

Kotecka S., Zalesińska A., Problemy prawne i techniczne archiwizowania materiałów z przestuchania na odległość, [w:] Materiały pokonferencyjne Świnoujście 14-17 maja 2009 r. Szczecin 14-17 września 2010 r., praca zbior., Wrocław 2010, s. 29-52.

Maślak D., Ośrodki Zarzązania Informacją. Nowa forma archiwizacji, [w:] Materiały pokonferencyjne Wrocław 2012-2013, praca zbior., Wrocław 2013, s. 118-124. 
Owczarek B., Maślak D., Centralne Archiwum Protokołów Elektronicznych - status prawny $i$ organizacyjny, http://www.saws.pl/asp/pl_start.asp?typ $=14 \& m e n u=42 \&$ strona $=1$ [dostęp: 2.12.2020].

Perłakowska E., Jednolity Rzeczowy Wykaz Akt w jednostkach wymiaru sprawiedliwości, http:// www.saws.pl/asp/pl start.asp?typ=14\&menu=42\&strona=1 [dostęp: 2.12.2020].

Perłakowska E., Narzędzia informatyczne w bieżacym i archiwalnym zarządzaniu dokumentacja $w$ podmiotach działajacych $w$ systemie tradycyjnym, http://www.saws.pl/asp/pl start.asp?ty$\mathrm{p}=14$ \&menu=42\&strona $=1$ [dostęp: 2.12 .2020$]$.

Podlasie24 Regionalny Portal Informacyjny. W Siedlcach powstaje Ośrodek Zarzadzania Informacją, http://podlasie24.pl/wiadomosci/siedlce/w-siedlcach-powstaje-osrodek-zarzadzania-informacja-896e.html [dostęp: 13.06.2020].

Sprawozdanie z XIII Konferencji, Warszawa 19-22 kwietnia 2016 r., http://www.saws.pl/asp/pl start.asp?typ=13\&sub=0\&menu=2\&artykul=82\&akcja=artykul [dostęp: 1.12.2020].

Stowarzyszenie Archiwistów Instytucji Wymiaru Sprawiedliwości. Z życia SAWS. Spotkanie w NDAP w Warszawie, http://www.saws.pl/asp/pl_start.asp?typ=13\&sub=0\&

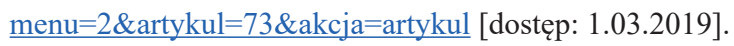

Stowarzyszenie Archiwistów Instytucji Wymiaru Sprawiedliwości. Z życia SAWS. Spotkanie z Dyrektorami Naczelnymi Archiwów Państwowych, http://www.saws.pl/asp/pl_start. asp?typ $=13 \&$ sub $=0 \&$ menu=2\&artykul=64\&akcja=artykul [dostęp: 1.03.2019].

Stowarzyszenie „Archiwizjoner”, https://web.facebook.com/archiwizjoner/ [dostęp: 15.02.2019].

Widawska A., Sprawozdanie z XII Konferencji SAWS, Szczecin 6-9 maja 2015 r., http://www.saws. $\mathrm{pl} / \mathrm{asp} / \mathrm{pl}$ _start.asp?typ=13\&sub=0\&menu=2\&artykul=79\&akcja=artykul [dostęp: 1.12 .2020$]$.

Zalesińska A., Protokót sądowy sporzadzany za pomoca urządzeń rejestrujących dźwięk albo obraz i dźwięk, jako dokument elektroniczny i jego archiwizacja, [w:] Materiały pokonferencyjne Wroctaw 2012-2013, praca zbior., Wrocław 2013, s. 35-37. 